\title{
Expression profile of water-soluble proteinases during ontogenesis of Megachile rotundata: an electrophoretic investigation
}

\author{
Antonio FeliCIOLI ${ }^{\mathrm{a} *}$, Elena DONADIO $^{\mathrm{a}}$, Ettore BALESTRERI $^{\mathrm{b}}$, Giorgio MONTAGNOLI $^{\mathrm{a}}$, \\ Romano FELICIOLI ${ }^{\mathrm{a}, \mathrm{b}}$, Adriano PODESTÀ ${ }^{\mathrm{a}}$ \\ a Dipartimento di Anatomia, Biochimica e Fisiologia Veterinaria, Università di Pisa, Viale delle Piagge 2, \\ 56124 Pisa, Italia \\ b Istituto di Biofisica del C.N.R., Area della Ricerca di Pisa, loc. S. Cataldo, Via G. Moruzzi 1, 56100 Pisa, Italia
}

(Received 30 September 2003; revised 13 January 2004; accepted 20 February 2004)

\begin{abstract}
Variations in proteinase activity pattern in larva, pupa and imago of the solitary bee Megachile rotundata are described. Extraction of insect homogenates under mild conditions was followed by the electrophoretic separation of the protein extract in polyacrylamide gels, precast with either gelatine or pollen protein extracts. In these conditions, twelve distinct proteinases were detectable in the pooled I-IV instar larvae, six in the pollen-eating $\mathrm{V}$ instar, two in the mature $\mathrm{V}$ instar, none in the diapausing $\mathrm{V}$ instar, none in the pupa, and two in the imago. Some of the detected proteinases were able to digest the protein mixture extracted from the pollen provisions. Some proteinases were insect specific since they were not detectable in pollen provisions extract. The enzymologic properties of the major proteolytic band suggest its serine-proteinase nature.
\end{abstract}

solitary bee / Megachile rotundata / development / proteinase / zymography

\section{INTRODUCTION}

In recent years both natural and transgenic protein-inhibitors of proteinases have received great attention for their potential use in inhibiting the digestive process of developing larvae of pest insects (Hilder et al., 1987; Johnson et al., 1989; Ryan, 1990). As a consequence, a wide range of investigations have been focused on the characterisation and identification of different target proteinases in a variety of insect orders: Lepidoptera, such as Agrotis (Purcell et al., 1992), Cydia (Christeller et al., 1992), Spodoptera (Lee and Anstee, 1995), Lymantria (Valaitis, 1995), Heliothis (Johnston et al., 1995), Ostrinia (Bernardi et al., 1996), Bombyx (Nobuyasu and Yamashita, 1997), Sesamia (Novillo et al., 1999), Pieris (Broadway, 1995); in Coleoptera, such as Adalia (Murdock et al.,
1987; Walker et al., 1998), Tenebrio (Dadd, 1956; Jang et al., 1998) and Tribolium (BlancoLabra et al., 1996); in Diptera, such as Aedes (Fisk, 1950) and Aenopheles (Berner et al., 1983; Vizioli et al., 2001); in Hemiptera, such as Dysdercus (Khan and Ford, 1962); and in Orthoptera, such as Locusta (Khan, 1963). The potential damage of protein-inhibitors on the digestive proteinases of beneficial insects has received less attention. Some proteinases have been described in Hymenoptera such as Vespula (Grogan and Hunt, 1977), Solenopsis (Botos et al., 2000) Apis (Dahlmann et al., 1978) and Scaptotrigona (Shumaker et al., 1993). In Bombus terrestris, some proteinases have been investigated by testing the effect of proteinase inhibitors on the survival of worker bumblebees (Malone et al., 2000).

\footnotetext{
* Corresponding author: antonio.felicioli@vet.unipi.it
} 
The solitary bee Megachile rotundata (Fabricius) is the most effective pollinator of alfalfa, it is commercially available and is extensively used in crop breeding (Pesenko, 1982; Krunić et al., 1995; Piano et al., 1998). It provides its brood with pollen actively collected during its foraging activity (Horne, 1995a). Pollen is stored in a pedotrophic cell built by lining the internal surface of a pre-existing tunnel with leave fragments (Horne, 1995b). An egg is laid on the pollen provision and subsequently the cell is sealed (Fairey et al., 1989; Pinzauti, 2000). After the egg hatches, the larva develops throughout five instars (Banaszak and Romasenko, 1998) feeding on the provisioned pollen. The pollen intake stops when the mature fifth instar is reached. After the cocoon is spun, the larva enters a seven to -nine month diapause period followed by metamorphosis and pupation. Throughout ontogenesis, proteolytic enzymes digest pollen proteins and are involved in protein phenotype remodelling. Thus, the use of proteinase protein-inhibitors could have dramatic consequences on the population of this beneficial insect. To our knowledge, no information is available on the pattern of proteolytic enzymes in Megachile rotundata during ontogenesis.

The aim of this work is to describe the pattern of the major proteinases during the ontogenesis of Megachile rotundata by means of zimography (Heussen and Dowdle, 1980). Various proteinases also have been described in both the pollen provisions (Grogan and Hunt, 1979; Schumaker et al., 1993) and in alfalfa leaves used to line the brood cells (Gonnelli et al., 1985) which would potentially contaminate our larval extracts. Therefore, the proteinase activities in the crude extract of alfalfa leaves and pollen provision were investigated.

\section{MATERIALS AND METHODS}

\subsection{Chemicals}

Chemicals and high-purity solvents were obtained from Sigma Chemical (St Louis, MO).

\subsection{Biological samples}

Insect specimens came from a releasing and rearing campaign performed in the coastal area of Tus- cany (Italy) during the June-July 1999 in the Laboratory of Apidology of Pisa University. Five larval stages were identified on the basis of both size and presence of the previous instar exuvia (Rust et al., 1989). Because of their small size, larvae belonging to the first, second, third and fourth instars were pooled before analysis (sample 1), while the fifth instar larvae were separated into the following three subgroups: pollen-eating V instar (sample 2), mature V instar (sample 3) and diapausing V instar (sample 4). Pupae were collected as they reached the black eye stage (sample 5). The female imagos were collected during nesting activity (sample 6).

The leaves and pollen grains were collected from the pedotrophic nest. All samples were stored frozen at $-20{ }^{\circ} \mathrm{C}$ until used.

\subsection{Crude extracts preparation}

After thawing, insects, pollen and leaves were homogenised with $50 \mathrm{mM}$ Tris- $\mathrm{HCl} \mathrm{pH} 8.0$ ( $0.1 \mathrm{~g}$ of insect $/ \mathrm{mL}$ of buffer, $0.25 \mathrm{~g}$ of pollen/mL of buffer, $0.1 \mathrm{~g}$ of leaves $/ \mathrm{mL}$ of buffer) at room temperature. Sixty specimens of each sample were used for extraction, 3 extractions of 20 specimens each. Five $\mathrm{g}$ of pollen and $3 \mathrm{~g}$ of leaves, coming from 30 pedotrophic cells, were used for extraction for a total of 3 extractions. The homogenates were then centrifuged at $2500 \times g$ for $15 \mathrm{~min}$ at $4{ }^{\circ} \mathrm{C}$ for debris removal and at $30000 \times g$ for $40 \mathrm{~min}$ at the same temperature for supernatant clarification. Total protein content was determined by the colorimetric method of Bradford (1976) using ovalbumin as reference protein and equalized in the different samples by dilution with the same buffer. The supernatants were then stored at $-20{ }^{\circ} \mathrm{C}$ until analysed.

\subsection{Zymography}

Zymography was performed in a Miniprotean II apparatus (Bio-Rad Laboratories, Hercules, CA). Proteins in the clarified extracts from the pollen, leaves and each bee sample underwent proteolytic activity-staining electrophoresis (Heussen and Dowdle, 1980 ), using $0.1 \%$ gelatine as precast protein substrate in a discontinuous $12 \%$ T Laemmli's electrophoresis system under semi-denaturing conditions (before loading, samples were 1:2 diluted with $2 \%$ SDS without boiling). No $\beta$-mercaptoethanol was added. Ten $\mu \mathrm{L}$ of each clarified extracts $(\simeq 15 \mu \mathrm{g}$ of proteins) were loaded in each lane. After electrophoresis, gels were shaken gently at room temperature for $30 \mathrm{~min}$ in $100 \mathrm{~mL} 2 \%$ Triton X-100 in water to remove SDS and restore full enzyme activity. Gels were then transferred to a bath containing $100 \mathrm{mM}$ Tris-HCl buffer, $\mathrm{pH} 8.0$ and kept under mild shaking, at $37{ }^{\circ} \mathrm{C}$ for 2 hours, then stained with $0.1 \%$ Blue 
Table I. The effect of various serine-proteinases inhibitors on the activity of the major band ( $\mathrm{Rm} \mathrm{0.48).}$

\begin{tabular}{lc}
\hline Inhibitor & $\%$ Inhibition \\
\hline Leupeptin $(20 \mu \mathrm{M})$ & 100 \\
$\begin{array}{l}\text { Pancreatic bovine trypsin inhibitor } \\
(\text { Kunitz })(20 \mu \mathrm{M})\end{array}$ & 93 \\
Soybean Trypsin Inhibitor $(20 \mu \mathrm{M})$ & 93 \\
$\begin{array}{l}\text { Tosyl-Lysine chloromethyl ketone } \\
\text { hydrochloride (TLCK) }(2 \mathrm{mM})\end{array}$ & 86 \\
$\begin{array}{l}\text { Lima Bean trypsin inhibitor }(20 \mu \mathrm{M}) \\
\text { Phenylmethylsulfonyl fluoride }(\mathrm{PMSF})\end{array}$ & 84 \\
$(2 \mathrm{mM})$ & 80 \\
$\begin{array}{l}\text { Chicken egg white ovomucoid, Type III } \\
(20 \mu \mathrm{M})\end{array}$ & 60 \\
Bowman Birk Inhibitor $(20 \mu \mathrm{M})$ & 46 \\
\hline
\end{tabular}

R250 Coomassie and de-stained with $40 \%$ methanol and $10 \%$ acetic acid.

Zymography of extracts from each larval sample was also performed with gel cast with $0.1 \%$ pollen extract instead of gelatine, to assess the activity of the identified proteinase(s) on the actual proteinsubstrates. Each electrophoresis run was repeated five times.

The major activity band (see below under Result section) was chosen for inhibition, optimal $\mathrm{pH}$ activity, thermal stability and molecular mass estimation. For the inhibition assay, the slabs were incubated separately in $2 \%$ Triton $\mathrm{X}-100$ for $30 \mathrm{~min}$, then at $37{ }^{\circ} \mathrm{C}$ for 2 hours in $100 \mathrm{mM}$ Tris-Cl pH 8 buffer containing the inhibitor; a total of eight inhibitors were tested. The inhibitors and the concentrations used are reported in Table I. The same experiment was carried out testing $2 \mathrm{mM}$ of $\mathrm{MgCl}_{2}, \mathrm{MnCl}_{2}, \mathrm{CaCl}_{2}$, $\mathrm{CoCl}_{2}$, EDTA. For the optimal pH activity assay, electrophoretic slabs of the same crude extract sample were incubated each in $2 \%$ Triton X-100 for $30 \mathrm{~min}$, then at $37^{\circ} \mathrm{C}$ for 2 hours in a $100 \mathrm{mM}$ buffer. The buffer was Tris-acetate at $\mathrm{pH} \mathrm{5,6}$ and 7; Tris$\mathrm{HCl}$ at $\mathrm{pH} 8$ and $\mathrm{pH}$ 9; and Borate at $\mathrm{pH} 10$ and 11 . For the thermal stability assay, 10 aliquots of the crude extract of the sample corresponding to the chosen electrophoretic lane were separately incubated for $10 \mathrm{~min}$ at $4{ }^{\circ} \mathrm{C}, 25^{\circ} \mathrm{C}, 30^{\circ} \mathrm{C}, 35^{\circ} \mathrm{C}, 40^{\circ} \mathrm{C}$, $45^{\circ} \mathrm{C}, 50{ }^{\circ} \mathrm{C}, 55^{\circ} \mathrm{C}, 60^{\circ} \mathrm{C}$, and $65^{\circ} \mathrm{C}$ prior to the electrophoresis run.

\subsection{Gel analysis}

Single lanes were densitometrically scanned and data analysed by means of the Quantity One 4.2.3 software (Bio-Rad Laboratories). White bands were identified and circled and the activity was expressed as the sum of the pixel intensities abbreviated as p.i.

\subsection{Determination of molecular mass of the major active band}

A volume of $200 \mu \mathrm{L}$ of sample 1 crude extract solution $(14.5 \mathrm{mg} / \mathrm{mL})$ was fractionated by gel-filtration on a Superdex 75 HR 10/30 column, equilibrated and eluted with $100 \mathrm{mM}$ Tris- $\mathrm{HCl}, \mathrm{pH} 8$, containing $50 \mathrm{mM} \mathrm{NaCl}$, at a flow rate of $0.4 \mathrm{~mL} / \mathrm{min}$. The eluate was monitored by absorbance at $280 \mathrm{~nm}$; the fractions were spectrophotometrically tested for activity by using N-Benzoyl-Phenylalanyl-ValylArginine-p-Nitroanilide as substrate (Erlanger et al., 1961). The fractions containing the major activity peak were pooled. The molecular mass was then calculated by applying markers protein of known molecular mass to the same column in the same buffer and rate flow condition as the crude extract. Standard markers were bovine serum albumin $(66 \mathrm{kDa})$, ovalbumin $(45 \mathrm{kDa})$, mioglobin $(16.95 \mathrm{kDa})$ and apro$\operatorname{tinin}(6.5 \mathrm{kDa})$.

\section{RESULTS}

\subsection{Proteolytic pattern variations}

Figure 1 shows the PAGE zymography on a gelatine precast gel, of protein extracts from Megachile rotundata at different developmental stages with the scanning record (trace) super-imposed on each lane. In the pooled I-IV instar larvae, twelve activity bands of different intensities were revealed, with $\mathrm{Rm}$ ranging from 0.03 to 0.50 (lane 1 ) and a major activity band at $0.48 \mathrm{Rm}$. In the pollen-eating $\mathrm{V}$ instar (lane 2), six bands were detectable, and in the following mature $\mathrm{V}$ larval stage (lane 3 ), only two bands were visible. In the diapausing and pupa stages (lane 4 and lane 5) no proteolytic activities were observed. In the imago extract, two very faint bands at 0.48 and $0.50 \mathrm{Rm}$ were detectable.

The 3D-histogram in Figure 2 shows the activity of each proteolytic band for all the samples investigated. As soon as the IV instar development was complete, the band intensities decreased at different rates. Only the bands at 0.03 and $0.07 \mathrm{Rm}$ were still detectable in the mature larva. After this stage, all proteinases became undetectable until the imago stage was reached, when the $0.48 \mathrm{Rm}$ band showed an intensity corresponding almost to the $5.6 \%$ of the initial value of the pooled I-IV instar larvae. 


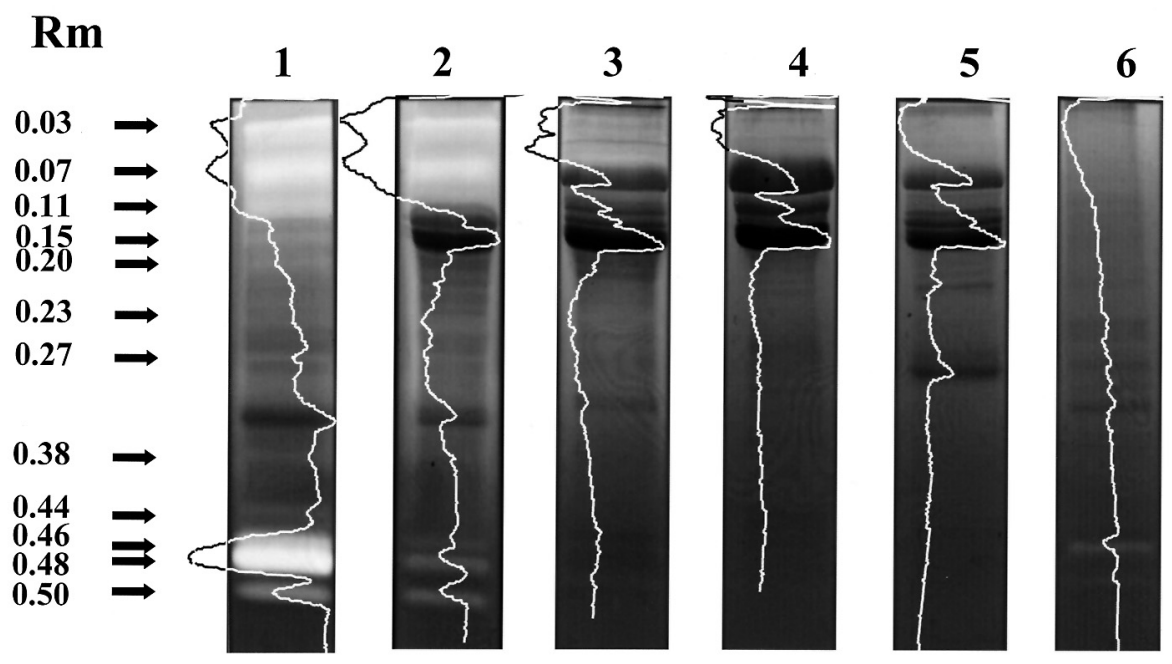

Figure 1. Gelatine-precast zymography PAGE of crude extract of Megachile rotundata. Proteins were separated in $12 \%$ T polyacrylamide gel containing $0.1 \%$ gelatine and incubated in $100 \mathrm{mM}$ Tris- $\mathrm{HCl}, \mathrm{pH} 8$ at $37{ }^{\circ} \mathrm{C}$ for two hours. The slabs were stained with Coomassie Blue and de-stained. Sixteen $\mu \mathrm{g}$ of crude protein extracts were loaded per lane. Lane 1, pooled I-IV instar larvae; lane 2, pollen-eating V instar larva; lane 3, V instar mature larva; lane 4, diapausing larva; lane 5, pupa; lane 6, imago. Densitometric records are superimposed. $\mathrm{Rm}$ value for each activity band is shown.

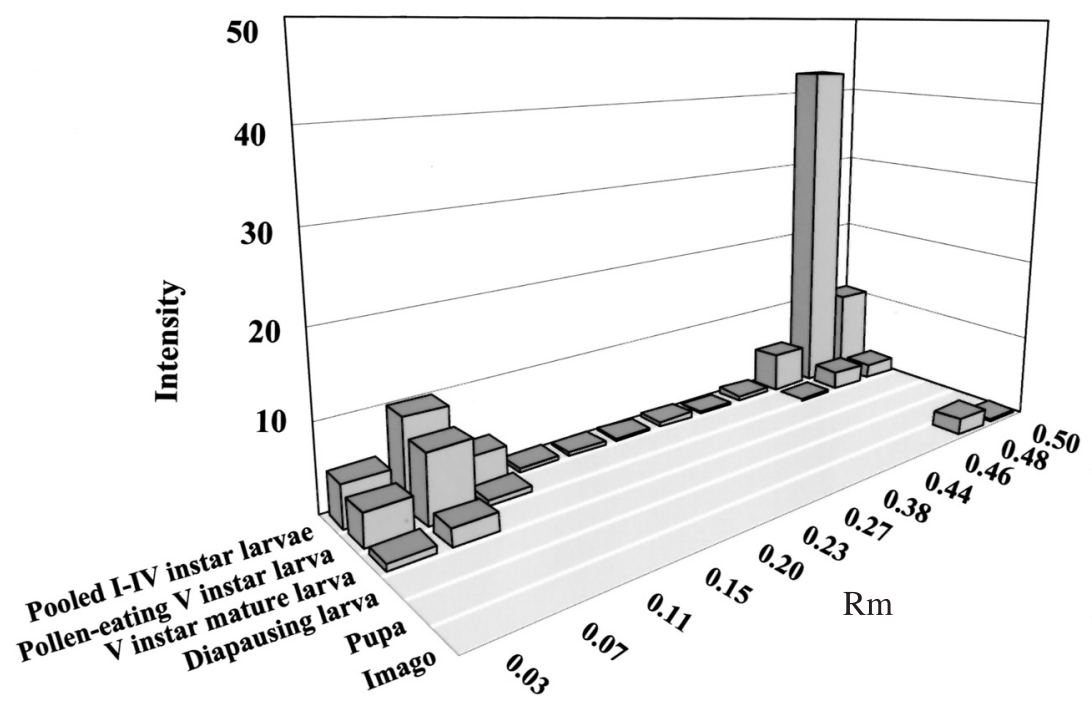

Figure 2. Densitometric evaluation of proteinase activities detected by zymography of larval, pupal and imago crude extract.

When the partially denatured artificial protein substrate (e.g. gelatine) was replaced by the natural protein substrate (e.g. the protein extract of the pollen provisions) the disappearance of the two broad bands ( $\mathrm{Rm} 0.03$ and 0.15 ) in sample 1 and of only one band ( $\mathrm{Rm} 0.03)$ in sample 2 was observed (Fig. 3).

Figure 4 shows a single proteolytic band that occurs in the crude extract of the pollen provision at $0.48 \mathrm{Rm}$ and 1693 p.i. activity. Under 


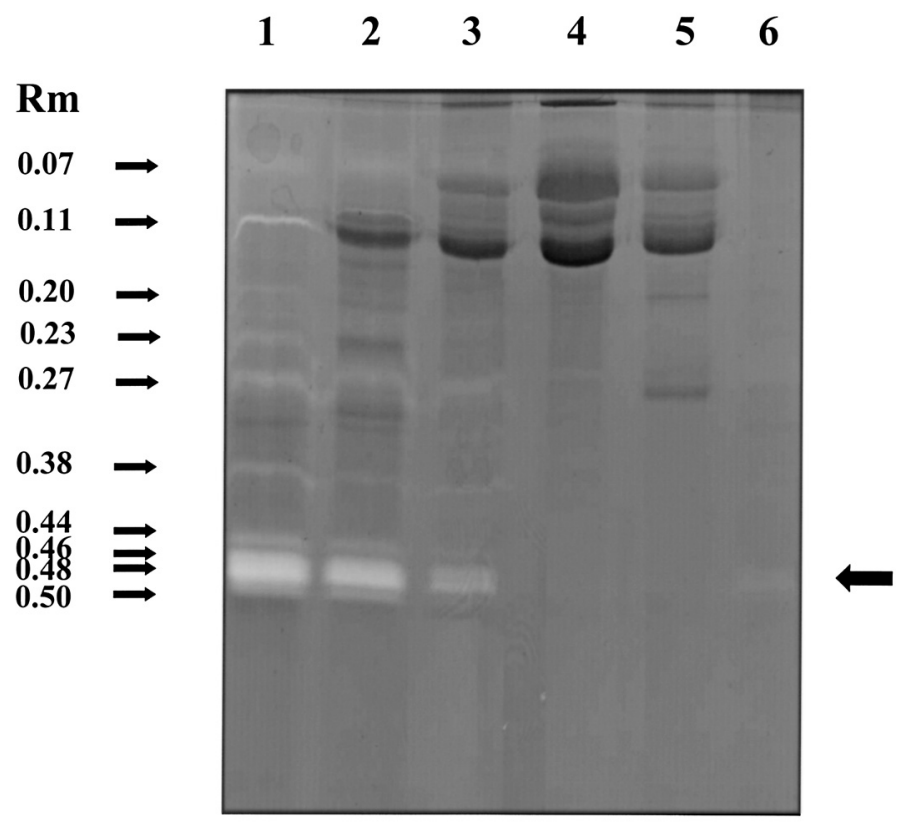

Figure 3. Pollen-precast zymography PAGE of crude extract of Megachile rotundata. Proteins were separated in $12 \% \mathrm{~T}$ polyacrylamide gel containing $0.1 \%$ pollen and incubated in $100 \mathrm{mM} \mathrm{Tris}-\mathrm{HCl}, \mathrm{pH} 8$ at $37^{\circ} \mathrm{C}$ for two hours. The slabs were stained with Coomassie Blue and de-stained. Thirty-two $\mu \mathrm{g}$ of crude protein extracts were loaded per lane. Lane 1, pooled I-IV instar larvae; lane 2, pollen-eating V instar larva; lane 3, V instar mature larva; lane 4, diapausing larva; lane 5, pupa; lane 6, imago. Rm value for each activity band is shown.

the same experimental conditions, no proteolytic activity was detectable in the extract of alfalfa leaves sampled in the pedotrophic nest (data not shown).

\subsection{Partial characterisation of the major active $0.48 \mathrm{Rm}$ band}

Figure 5 shows the activity variation of the protease within the $\mathrm{pH}$ range investigated. The curve shows an activity range between 7 and 11 with a maximum peak between 8 and 9 .

When the PAGE slabs of the I-IV instar extract were developed in the presence of several natural and synthetic proteinase inhibitors, the results reported in Table I were obtained. The activity was inhibited according to the inhibitors used. In particular Leupeptin, Pancreatic bovine trypsin inhibitor (Kunitz), and Soybean Trypsin Inhibitor inhibited between $90 \%$ and $100 \%$. Divalent and/or monovalent cations and EDTA had no effect on the activity (data not shown).

Figure 6 shows a thermal stability of this proteinase activity up to $45^{\circ} \mathrm{C}$. Beyond this temperature the activity rapidly decreased to zero at $65^{\circ} \mathrm{C}$.

The pooled I-IV instar larval stage was applied on the Superdex 75 column and the eluted fractions were spectrophotometrically analysed for proteolytic activity using N-Benzoyl-Phenylalanyl-Valyl-Arginine-p-Nitroanilide as a substrate. The major activity peak emerged at an elution volume of $12.4 \mathrm{~mL}$, which when compared with the elution volumes of the used markers, gave a $25.6 \mathrm{kDa}$ molecular mass (Fig. 7). The fractions containing the major activity peak were pooled and analysed by PAGE zymography and only one band at Rm 0.48 was detected (data not shown).

\section{DISCUSSION}

In this work we demonstrated variation in the expression profile of several soluble proteinases during ontogeny of the solitary bee $\mathrm{Meg}$ achile rotundata by zymography PAGE in which the use of gelatine as the precast proteinsubstrate allowed detection of several bands 


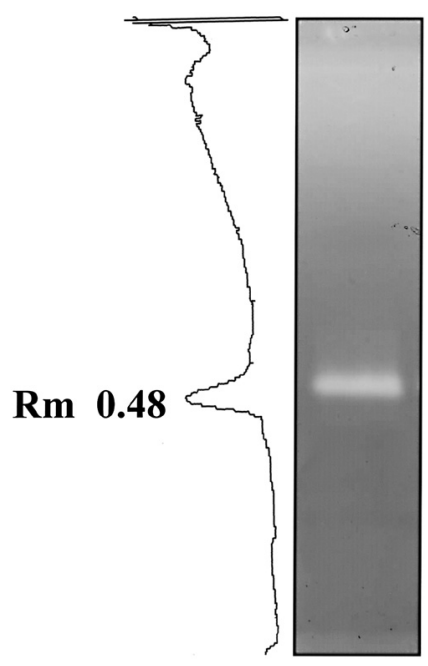

Figure 4. Gelatine-precast zymography PAGE of pollen provision sampled from the pedotrophic cell of Megachile rotundata. Proteins were separated in $12 \% \mathrm{~T}$ polyacrylamide gel containing $0.1 \%$ pollen and incubated in $100 \mathrm{mM}$ Tris- $\mathrm{HCl}, \mathrm{pH} 8$ at $37^{\circ} \mathrm{C}$ for two hours. The slab was stained with Coomassie Blue and de-stained. Twenty-five $\mu \mathrm{g}$ of crude protein extracts were loaded. Densitometric record and the $\mathrm{Rm}$ value is shown.

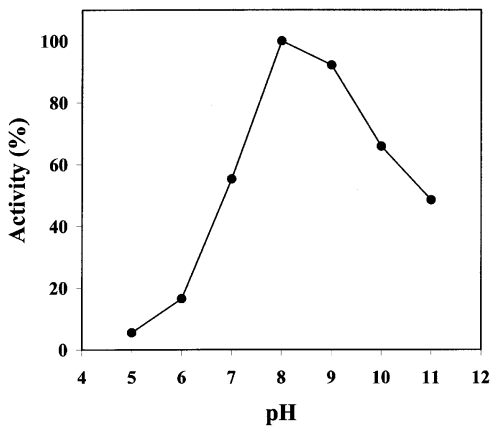

Figure 5. $\mathrm{pH}$ activity profile of the major band ( $\mathrm{Rm}$ 0.48 ) of the sample 1 (pooled I-IV instar larvae). Gelatine-precast zymography PAGE of the crude extract of sample 1 was carried out as in Figure 1 with the only exception being the incubation buffer. The incubation buffer at $\mathrm{pH} \mathrm{5,6}$ and 7 was $100 \mathrm{mM}$ Tris-acetate; at $\mathrm{pH} 8$ and 9 was $100 \mathrm{mM}$ Tris-HCl; and at pH 9 and 11 was 100 mM Borate.

present in a given crude extract. The gelatine is a mixture of denatured proteins and peptides of various lengths and as such is a good substrate for proteolytic enzymes with different substrate specificities. The use of sensitive scan-

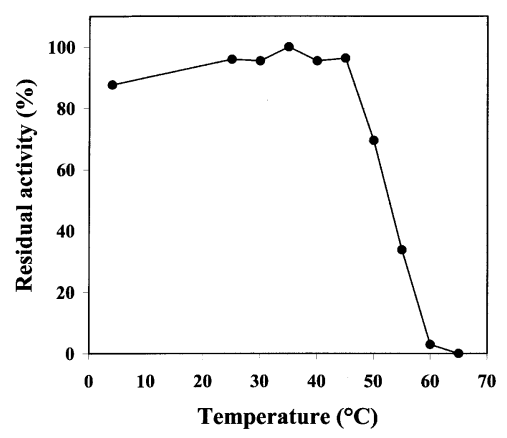

Figure 6. Thermal stability of sample 1 (pooled IIV instar larvae) major band proteinase ( $\mathrm{Rm} 0.48)$. The samples were incubated at the reported temperature for $10 \mathrm{~min}$ before the electrophoresis separation. The zymography was carried out as in Figure 1.

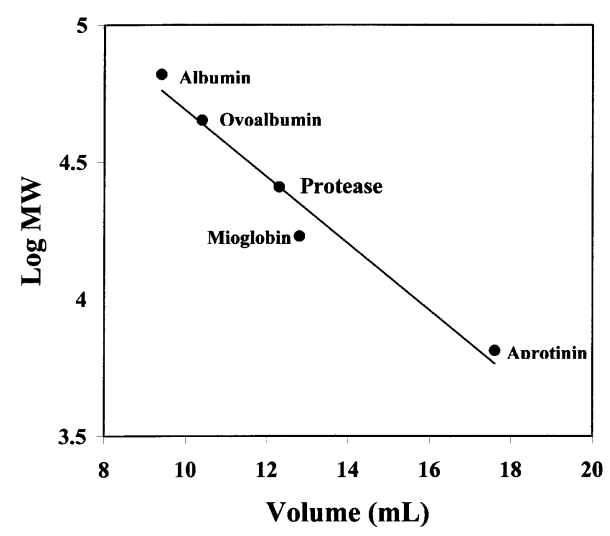

Figure 7. Molecular mass determination of the major component of the activity band. Plot of the elution volume vs. log molecular mass for the sample 1 major band proteinase ( $\mathrm{Rm} \mathrm{0.48)}$ and the marker proteins on Superdex 75 HR 10/30.

ning and quantifiable method renders it a useful tool for a comparative investigation of proteinase patterns in various biological samples (Vaccari et al., 1998; Nanni et al., 2001). We compared the detectable proteolytic activity of different extracts all treated under identical experimental conditions.

The most active band appeared in the I-IV instar larvae which are characterised by high growth rate and pollen intake. Both number and intensity fall to zero in the following instar in which no pollen intake occurs. Due to our experimental conditions, proteolytic enzymes 
required by re-modelling process in prepupae and pupae, may have been overlooked. Our results suggest that the $0.48 \mathrm{Rm}$ band relates to growth and pollen intake.

The presence of the faint active bands in the imago extract could be due to feeding on pollen by the adult during its first days of imago life as well to the contamination of the nectar by pollen grains. These grains contain both chymotrypsin-like (Grogan and Hunt, 1979) and cysteine proteinases (Schumaker et al., 1993) (hardly detectable in our conditions).

Therefore, we can hypothesise that the band at $\mathrm{Rm} 0.48$ may partly come from the pollen in the pollen eating instars, and it may be derived entirely from the pollen eaten by the imago.

The comparison between the gels with precast gelatine and those with precast protein extract from pollen provisions showed two main differences: a general reduction of intensity of the bands and the disappearance of 0.03 and $0.15 \mathrm{Rm}$ activity band in lane 1 . The general reduction in intensity can be ascribed to the denatured gelatine proteins as compared to the native state of the pollen proteins. The lack of the two bands in the pooled I-IV instar extract can be ascribed to the same cause and can be interpreted as the lack of two enzyme such as the peptidyl-peptidase family which shows small peptides substrate specificity. However, the comparison clearly indicated that at least ten of the twelve bands originally occurring in the pooled I-IV instar extract were able to digest the natural native protein and all of them were absent in the non-pollen eating stages.

The high number of activities we found in sample 1 in both gelatine- and pollen-precast gels and their decrease throughout the pollenintake larval phase strongly suggest that these detectable proteinases may be involved in pollen digestion. This hypothesis is in agreement with data concerning the presence of several proteolytic activities with a digestive role at alkaline $\mathrm{pH}$ detectable in the midgut of several insects (Purcell et al., 1992; Walker et al., 1998; Jimenez and Gilliam, 1989). These data have been emphasized on the basis of observations concerning the digestion physiology in the bee S. bipunctata that involve aminopeptidase and trypsin enzyme (Schumaker et al., 1993). The large repertoire of the proteolytic enzymes of the pollen-eating growing larvae (lane 1 in Fig. 1 and Fig. 3) could permit the complete digestion of the food proteins since many proteinases with different scissile bond specificities are required to complete the protein digestion to single amino-acids able to be absorbed by the intestine epithelium. The decrease of the proteolytic activities of all the bands throughout the investigated larval phases is in agreement with previous findings in Apis mellifera, where two chymotrypsin- and two trypsin-like proteinases with a digestive role have been described in the midgut of larval and adult worker honeybees (Dahlmann et al., 1978). Grogan and Hunt $(1980,1984)$ found out that chymotrypsin-like enzymes of young adults of worker honeybees that still feed on pollen followed a seasonal pattern, coinciding with periods of elevated pollen consumption, while the trypsin-like ones decreased with ageing which suggests that these proteinases do not have a digestive role. Indeed, the young adult honeybees still eat pollen for five to ten days after emergence when they are generally considered to be nurse bees (Jimenez and Gilliam, 1989; Crailsheim et al., 1992). Pollen consumption at this age would initiate both digestive enzyme synthesis and hypo-pharyngeal gland development (Brouwers, 1982).

No proteinase activities have been detected in the crude extract of leaves indicating that none of the bands detected in the bee samples have leaf origin. A band at Rm 0.48 was found in the pollen provision crude extract (Fig. 4), indicating that all the other activity bands detected in both gelatine and pollen provision precast gel were insect-specific, which is in agreement with the findings of Schumaker et al. (1993) concerning the bee $S$. bipunctata.

The activities of the three $\mathrm{Rm} 0.48$ bands were 1693 p.i., 236 p.i., and 4250 p.i., for pollen, imago and pooled I-IV instar extracts, respectively. The exceedingly high activity of the growth and pollen-eating larval band, compared to the intensity of the pollen provision band, rules out the possibility of the former being solely due to pollen contamination and strongly supports the hypothesis that the greatest part of the activity belongs to the larva itself. From our figures we can draw the conclusion that in this sample (pooled I-IV instar) at least $75 \%$ of the $0.48 \mathrm{Rm}$ proteinase was of larval origin. In contrast, from an analogous calculation it is possible to deduce that the imago band 
was mainly due to the contamination by pollen grains present in the ingested nectar.

The sample $1 \mathrm{Rm} 0.48$ band showed the major activity at a $\mathrm{pH} 8$, and showed heat stability up to $45^{\circ} \mathrm{C}$. A similar result was reported by Bernardi et al. (1996) for the proteinase of corn borer (Ostrinia nubilalis). The optimum at alkaline $\mathrm{pH}$ and the thermal stability behaviour of this enzyme are similar to that observed for proteinase belonging to lepidoptera larvae (Bernardi et al., 1996; Christeller et al., 1992). The estimated molecular mass of $25.6 \mathrm{kDa}$ of the major activity band of $M$. rotundata is comparable with that of bovine trypsin $(24 \mathrm{kDa})$ and chymotrypsin $(25 \mathrm{kDa})$ as also with trypsin from Spodoptera littoralis (24 kDa) (Lee and Anstee, 1995). Moreover, the activity of the $\mathrm{Rm} 0.48$ band was inhibited by typical trypsin and chymotrypsin inhibitors (see Tab. I) and it did not require metal ions or EDTA. These data together strongly suggest that the enzyme responsible for the major activity band has a serineproteinase-like nature.

\section{ACKNOWLEDGMENTS}

The present work was supported by Regione Toscana, Italia. Authors are indebted to the experience and knowledge of Dr. Mauro Pinzauti. They wish also to thank Dr. Andrea Frediani for his technical support.

Résumé - Profils d'expression des protéases digestives au cours du développement de Megachile rotundata (Hymenoptera : Megachilidae) : étude par électrophorèse. Durant tout le développement de Megachile rotundata les enzymes protéolytiques digèrent les protéines et sont impliqués dans le remodelage phénotypique. L'utilisation d'inhibiteurs de protéases (IP) pourrait avoir des conséquences dramatiques dans les populations d'insectes auxiliaires. Aucune information n'est disponible à notre connaissance sur la protéolyse durant l'ontogenèse de cette abeille. Ce travail décrit quelques modifications dans le déroulement de l'activité des protéinases qui peuvent être observées au cours de la vie de $M$. rotundata à l'aide de la zymographie. En raison de la petitesse de leur taille, les larves des 4 premiers stades ont été regroupées avant l'analyse (échantillon 1), tandis que les larves du $5^{\mathrm{e}}$ stade ont été réparties en trois sous-groupes : larves $\mathrm{V}$ consommant du pollen (échantillon 2), larves $\mathrm{V}$ matures (échantillon 3) et larves $\mathrm{V}$ en diapause (échantillon 4). Les nymphes ont été prélevées lorsqu'elles atteignaient le stade yeux noirs (échantillon 5) et les adultes femelles lorsqu'elles nidifiaient (échantillon 6). Les feuilles garnissant le nid et les grains de pollen ont également été prélevés dans les nids pédotrophi- ques en tant que pollutions éventuelles. Les échantillons ont été conservés à $-20^{\circ} \mathrm{C}$ jusqu'à leur utilisation. Après décongélation, les insectes et, comme témoins, le pollen et les feuilles ont été extraits dans $50 \mathrm{mM}$ de Tris- $\mathrm{HCl} \mathrm{pH} 8,0$ à la température ambiante, évitant ainsi des conditions dénaturantes. Les protéines ont été ensuite séparées par électrophorèse sur gels de polyacrylamide, sur support soit de gélatine soit d'extraits de protéines de pollen et les protéines ont été révélées par zymographie. L'activité de la bande principale a été aussi caractérisée d'après sa sensibilité aux inhibiteurs, son activité $\mathrm{pH}$ optimum, sa stabilité thermique et sa masse moléculaire.

Douze protéinases différentes ont été détectées dans le groupe des larves de stade I à IV, six dans les larves de stade $\mathrm{V}$ consommant du pollen, deux dans les larves matures, aucune dans les larves en diapause, aucune dans les nymphes et deux chez les imagos (Figs. 1 et 2). Certaines des protéinases détectées étaient capables de digérer le mélange protéinique extrait des provisions de pollen (Fig. 3) et la bande $\mathrm{Rm} 0,48$ a été révélée aussi dans l'extrait de pollen (Fig. 4). En revanche aucune activité protéolytique n'a été détectée dans l'extrait de feuilles de luzerne prélevées dans le nid pédotrophique. L'activité dans la bande principale était détectable aux pH 7 à 11, avec un maximum à 8 et 9 (Fig. 5). Elle était inhibée par les huit inhibiteurs de protéinase à sérine testés (Tab. I). Les cations divalents et/ou monovalents et l'EDTA ont été inefficaces. L'activité s'est maintenue jusqu'à $45^{\circ} \mathrm{C}$. Au-delà de cette température elle a décru rapidement et disparu à $65^{\circ} \mathrm{C}$ (Fig. 6). La masse moléculaire a été estimée à $25,6 \mathrm{kDa}$ par chromatographie d'exclusion de taille (Fig. 7). Ces propriétés sont cohérentes avec une identification de l'activité comme étant d'une protéase à sérine.

\section{Megachile rotundata / développement postem- bryonnaire / protéinase / zymographie}

Zusammenfassung - Expressionsprofile wasserlöslicher Proteinasen während der Ontogenese von Megachile rotundata: eine elektrophoretische Untersuchung. Während der gesamten Individualentwicklung von Megachile rotundata verdauen die proteolytischen Enzyme Polleneiweiße und spielen bei der phänotypischen Umwandlung eine Rolle. Die Anwendung von Proteinasehemmern könnte daher dramatische Auswirkungen auf die Populationen dieser Nutzinsekten haben. Unseres Wissens nach bestehen über die Proteolyse während der Entwicklung dieser Bienen keine Kenntnisse. Diese Arbeit beschreibt einige Veränderungen des Verlaufs der Proteinaseaktivität die mittels Zymographie im Verlauf des Lebens von Megachile rotundata beobachtet werden kann.

Die Larven des ersten bis vierten Larvenstadiums wurden wegen ihrer geringen Größe vor der Analyse zusammengefasst (Probe 1). Dagegen wurden die Larven des 5. Stadiums in die drei Untergruppen 
Pollenfressende (Probe 2), Erwachsene (Probe 3) und Diapausierende (Probe 4) unterteilt. Probe 5 bestand aus Puppen, die das Stadium schwarzer Augen erreicht hatten. Die weiblichen ausgewachsenen Bienen wurden während der Nestbauaktivität gesammelt (Probe 6). Die möglichen Verunreinigungen von Nest auskleidenden Blättern und Pollenkörnern wurden ebenfalls aus den pedotrophischen Nestern gesammelt und bei $-20{ }^{\circ} \mathrm{C}$ bis zur Nutzung eingefroren. Nach dem Auftauen wurden die Insekten, und als Kontrolle die Pollen und Blätter, in $50 \mathrm{mM}$ Tris- $\mathrm{HCl} \mathrm{pH} 8,0$ unter Vermeidung von denaturierenden Bedingungen bei Raumtemperatur extrahiert. Die Proteine wurden dann unter Vorlage von entweder Gelatine oder Pollenproteinextrakten durch Polyacrylamid-Elektrophoresegele getrennt und die Proteine durch Zymographie bestimmt. Die Aktivität in der ausgeprägtesten Bande wurde weiterhin durch die Sensitivität gegen Inhibitoren, optimale $\mathrm{pH}$-Aktivität, thermische Stabilität und molekulare Masse charakterisiert. In den zusammengefassten Larvenstadien I-V waren 12 verschiedene Proteinasen auffindbar, in dem pollenfressenden V. Larvenstadium 6, zwei in den reifen Larven, keine in den diapausierenden und zwei in den Imagos (Abb. 1 und 2). Einige dieser Proteinasen waren in der Lage, die aus der Pollennahrung extrahierte Proteinmischung zu verdauen (Abb. 3) und die Rm 0,48 Bande war auch in den Pollenextrakten vorhanden (Abb. 4). In den Extrakten die aus den in pedotrophischen Nestern gesammelten Alfalfa Blättern gewonnen wurden, konnte dagegen keine proteolytische Aktivität gefunden werden. Die Aktivität der herausragenden Bande war in einem $\mathrm{pH}$-Bereich von 7-11 ermittelbar, mit einem Maximum zwischen 8 und 9 (Abb. 5). Sie wurde durch alle acht untersuchten Serinproteinaseinhibitoren gehemmt (Tab. I). Divalente und/oder monovalente Kationen und EDTA hatten keinen Einfluss. Die Aktivität wurde bis $45^{\circ} \mathrm{C}$ aufrechterhalten, oberhalb dieser Temperatur nahm sie rasch ab und verschwand bei $65^{\circ} \mathrm{C}$ (Abb. 7). Durch Größenausschlusschromatographie wurde eine Molekularmasse von $25.6 \mathrm{kDa}$ abgeschätzt. Diese Eigenschaften passen zu einer Identifikation der Aktivität als Serinproteinase.

Solitäre Bienen / Megachile rotundata / Entwicklung / Proteinase / Zymographie

\section{REFERENCES}

Banaszak J., Romasenko L. (1998) Megachilid bees of Europe (Himenoptera, Apoidea, Megachilidae), Pedagogical University of Bydgoszcz, Bydgoszcz, Polland.

Bernardi R., Tedeschi G., Ronchi S., Palmieri S. (1996) Isolation and some molecular properties of a trypsin-like enzyme from larvae of European corn borer Ostrinia nubilalis Hubner (Lepidoptera: Pyralidae), Insect Biochem. Mol. Biol. 26, 883-889.

Berner R., Rudin W., Hecker H. (1983) Peritrophic membranes and protease activity in the midgut of the malaria mosquito, Anopheles stephensi (Liston) (Insecta: Diptera) under normal and experimental conditions, J. Ultrastruct. Res. 83, 195204.

Blanco-Labra A., Martinez-Gallardo N.A., SandovalCardoso L., Delano-Frier J. (1996) Purification and characterization of a digestive cathepsin D proteinase isolated from Tribolium castaneum larvae (Herbst), Insect Biochem. Mol. Biol. 26, 95100.

Botos I., Meyer E., Nguyen M., Swanson S.M., Koomen J.M., Russell D.H., Meyer E.F. (2000) The structure of an insect chymotrypsin, J. Mol. Biol. 298, 895-901.

Bradford M.M. (1976) A rapid and sensitive method for the quantitation of microgram quantities of protein utilizing the principle of protein-dye binding, Anal. Biochem. 7, 248-254.

Broadway R.M. (1995) Are insects resistant to plant proteinase inhibitor? J. Insect Physiol. 41, $107-$ 116.

Brouwers E. (1982) Measurement of hypopharyngeal gland activity in the honeybee, J. Apic. Res. 21, 193-198.

Christeller J., Laing W., Markwick N., Burgess E. (1992) Midgut protease activities in 12 phytophagous lepidopteran larvae: dietary and protease inhibitor interactions, Insect Biochem. Mol. Biol. $22,735-746$.

Crailsheim K., Schneider L.H.W., Hrassnigg N., Bühlmann G., Brosch U., Gmeinbauer R., Schöffmann B. (1992) Pollen consumption and utilization in worker honeybees (Apis mellifera carnica): Dependence on individual age and function, J. Insect Physiol. 38, 409-419.

Dadd R. (1956) Proteolytic activity of the midgut in relation to feeding in the beatle Tenebrio molitor L. and Dytiscus marginalis L., J. Exp. Biol. 33, 311-324.

Dahlmann B., Jany K., Pfleiderer G. (1978) The midgut endopeptidase of the honeybee (Apis mellifica): comparison of the enzymes in different ontogenetic stages, Insect Biochem. 8, 203-211.

Erlanger B.F., Cocowsky N., Cohen W. (1961) The preparation and properties of two new chromogenic substrates of trypsin, Arch. Biochem. Biophys. 95, 271-278.

Fairey D.T., Lefkovitch L.P., Lieverse J.A.C. (1989) The leafcutting bees Megachile rotundata (F.) a potential pollinator for red clover, J. Appl. Entomol. 107, 52-57.

Fisk F. (1950) Studies on proteolytic digestion in adult Aedes aegypti mosquitos, Ann. Entomol. Soc. Am. 43, 555-572.

Gonnelli M., Cioni P., Romagnoli A., Gabellieri E., Balestreri E., Felicioli R. (1985) Purification and characterization of two leaf proteinase from Alfalfa (Medicago sativa), Arch. Biochem. Biophys. 238, 206-212.

Grogan D., Hunt J. (1977) Digestive proteases of two species of wasps of the genus Vespula, Insect Biochem. 7, 191-196.

Grogan D., Hunt J. (1979) Pollen proteinases: their potential role in insect digestion, Insect Biochem. 9, 309-313. 
Grogan D., Hunt J. (1980) Age correlated changes in midgut proteinase activity of the honeybee, Apis mellifera (Hymenoptera: Apidae), Experientia 36, 1347-1348.

Grogan D., Hunt J. (1984) Chymotrypsin-like activity in the honeybee midgut: patterns in a three-year study, J. Apic. Res. 23, 61-63.

Heussen C., Dowdle E. (1980) Electrophoretic analysis of plasminogen activators in polyacrylamide gels containing sodium dodecyl sulfate and copolymerized substrates, Anal. Biochem. 102, 196202.

Hilder V., Gatehouse A., Sherman S., Barker R., Boulter D. (1987) A novel mechanism for insect resistance engineered into tobacco, Nature 330, 160-163.

Horne M. (1995a) Leaf area and toughness effects on nesting material preferences of Megachile rotundata (Hymenoptera: Megachilidae), Ann. Entomol. Soc. Am. 88, 868-875.

Horne M. (1995b) Pollen preference and its relationships to nesting success of Megachile rotundata (Hymenoptera: Megachilidae), Ann. Entomol. Soc. Am. 88, 862-867.

Jang K.S., Cho M.Y., Choi H.W., Lee K.M., Kim M.H., Lee Y.U., Kurata S., Natori S., Lee B.L. (1998) Purification and characterization of a $25 \mathrm{kDa}$ cathepsin L-like protease from the hemocyte of coleopteran insect, Tenebrio molitor larvae, J. Biochem. Mol. Biol. 31, 364-369.

Jimenez D., Gilliam M. (1989) Age related changes in the midgut ultrastructure and trypsin activity in the honey bee Apis mellifera, Apidologie 20, 287303.

Johnson R., Narvaez J., An G., Ryan C. (1989) Expression of proteinase inhibitors I and II in transgenic tobacco plants: effects on natural defense against Manduca sexta larvae, Proc. Natl. Acad. Sci. (USA) 86, 9871-9875.

Johnston K.A., Lee M.J., Brough G., Hilder V.A., Gatehouse A.M.R., Gatehouse J.A. (1995) Protease activities in the larval midgut of Heliothis virescens - Evidence for trypsin and chymotrypsin-like enzymes, Insect Biochem. Mol. Biol. 25, 375-383.

Khan M.A. (1963) Studies on the secretion of digestive enzymes in Locusta migratoria L. I. Proteinase activity, Entomol. Exp. Appl. 6, 181-193.

Khan M.R., Ford J.B. (1962) Studies on digestive enzyme production and its relationship to the cytology of the midgut epiyhelium in Dysdercus fasciatus Sign, (Hemiptera, Pyrrhocoridae), J. Insect Physiol. 8, 597-608.

Krunić M., Tasei J., Pinzauti M. (1995) Biology and management of Megachile rotundata Fabricius under European conditions, Apicoltura 10, 71-97.

Lee M., Anstee J. (1995) Endoproteases from the midgut of larval Spodoptera littoralis include a chymotrypsin-like enzyme with an extended binding site, Insect Biochem. Mol. Biol. 25, 49-61.

Malone L.A., Burgess E.P.J., Stefanovic D., Gatehouse H.S. (2000) Effects of four protease inhibitors on the survival of worker bumblebees, Bombus terrestris L, Apidologie 31, 25-38.

Murdock L., Brookhart G., Dunn P., Foard D., Kelley S., Kitch L., Shade R., Schukle R., Wolfson J.
(1987) Cysteine digestive proteinases in Coleoptera, Comp. Biochem. Physiol. B 87, 783-787.

Nanni B., Balestreri E., Dainese E., Cozzani I., Felicioli R. (2001) Characterisation of a specific phycocyanin-hydrolysing proteinase from Spirulina platensis, Microbiol. Res. 156, 259-266.

Nobuyasu M., Yamashita O. (1997) Purification and characterization of a protease degrading $30 \mathrm{kDa}$ yolk proteins of the silkworm, Bombyx mori, Insect Biochem. Mol. Biol. 27, 721-728.

Novillo C., Castanera P., Ortego F. (1999) Isolation and characterization of two digestive trypsin-like proteinases from larvae of the stalk corn borer, Sesamia nonagrioides, Insect Biochem. Mol. Biol. 29, 177-184.

Pesenko Yu. A. (1982) The Alfalfa leafcutting bee Megachile rotundata and its management for pollination of alfalfa, Nauka, Leningrad, USSR (in Russian).

Piano E., Pinzauti M., Annicchiarico P., Felicioli A., Precetti L., Romani M. (1998) Impollinazione in ambiente confinato mediante Apoidei solitari nel miglioramento genetico di leguminose foraggere, Sementi Elette 2, 11-19.

Pinzauti M. (2000) Il Megachile rotundata (F.), in: Pinzauti M. (Ed.), Api e impollinazione, Regione Toscana Dipartimento dello sviluppo economico, Firenze, Italy, pp. 131-143.

Purcell J., Greenplates J., Sammons D. (1992) Examination of midgut luminal proteinase activities in six economically important insects, Insect Biochem. Mol. Biol. 22, 41-47.

Rust R., Torchio P., Trostle G. (1989) Late embryogenesis and immature development of Osmia rufa cornigera (Rossi) (Hymenoptera: Megachilidae), Apidologie 20, 359-367.

Ryan C. (1990) Protease inhibitors in plants: genes for improving defenses against insects and pathogens, Annu. Rev. Phytopathol. 28, 425-449.

Schumaker T.T.S., Cristofoletti P.T., Terra W.D (1993) Properties and compartimentalization of digestive carbohydrases and proteinases in Scaptotrigona bipunctata (Apidae: Meliponinae) larvae, Apidologie 24, 3-17.

Vaccari L., Melfi D., Balestreri E., Felicioli R. (1998) The presence in spinach (Spinacia olearacea L.) leaf of a novel proteinase and of its specific protein inhibitor, Plant Physiol. Biochem. 36, 427-432.

Valaitis A.P. (1995) Gypsy moth midgut proteinases: purification and characterization of luminal trypsin, elastase and the brush border membrane leucine aminopeptidase, Insect Biochem. Mol. Biol. 25, 139-149.

Vizioli J., Catteruccia F., della Torre A., Reckmann I., Muller H.M. (2001) Blood digestion in the malaria mosquito Anopheles gambiae: molecular cloning and biochemical characterization of two inducible chymotrypsins, Eur. J. Biochem. 268, 4027-4035.

Walker A.J., Ford L., Majerus M.E.N., Geoghegan I.E., Birch N., Gatehouse J.A., Gatehouse A.M.R. (1998) Characterisation of the mid-gut digestive proteinase activity of the two-spot ladybird (Adalia bipunctata L.) and its sensitivity to proteinase inhibitors, Insect Biochem. Mol. Biol. 28, 173 180. 